which in due course will enable us to define the distribution in statistical terms. In the meantime an R.V.D. ratio of less than unity indicates a vertebral density less than our standard. We are not yet prepared to define the reduction in bone density which justifies the use of the term " osteoporosis," but consider it axiomatic that vertebral bodies which are no denser than their disks are severely porotic. On this basis the data confirm our previous suggestion (Barnett and Nordin, 1960, 1961) that our original scoring procedure tends to underdiagnose osteoporosis-that is, it produces false negatives but no false positives. It would in fact appear from Fig. 7 that vertebral biconcavity develops at that stage in osteoporosis when the vertebral bodies have about the same radiographic density as the disks. It may seem surprising that the vertebral bodies can even become less dense than the disks, but we attribute this to the replacement of bony trabeculae by marrow fat.

Our results appear to resolve the problem of the difference between spinal and peripheral osteoporosis. We had previously suggested (Nordin, 1961 ; Barnett and Nordin, 1961) that peripheral osteoporosis might be a late stage in a disease process initiated in trabecular bone, particularly that of the spine, and had pointed out that the occurrence of pure peripheral osteoporosis might be an artifact of our original technique in that it failed to detect early spinal osteoporosis. This now appears to be the case. Examination of Fig. 6 shows that all our cases of peripheral osteoporosis with one exception have low R.V.D. ratios, and we are therefore satisfied that although spinal (that is, trabecular) osteoporosis may occur without peripheral (that is, cortical) osteoporosis, the reverse does not occur. In generalized osteoporosis the first loss of bone is trabecular and only later does cortical loss occur. This accords, with the experimental evidence of the effect of negative calcium balance in animals (Nordin, 1960), and is therefore compatible with the concept that clinical osteoporosis could be due to prolonged negative calcium balance.

\section{Summary}

A method is described for assessing the density of the lumbar vertebrae by comparison with the intervertebral disks. This procedure is designed to eliminate the effect of soft-tissue variation.

A lateral tomogram is obtained through the centre of the lumbar spine and of a dissected specimen of lumbar spine mounted in formol-saline and placed next to the subject.

The film images of the spine and standard are fed through a Laurence-Locarte recording densitometer and the difference between the average density of the disks and the average density of the bodies is determined. This difference in the spine is divided by the same difference in the standard, and the ratio is called the relative vertebral density.

The results obtained are compared with the $x$-ray scores of Barnett and Nordin. This comparison suggests that vertebral biconcavity develops at the stage when the vertebral body is of about the same density as the intervertebral disk.

In severe osteoporosis the vertebral bodies are less dense than the intervertebral disks.

This work was carried out during the tenure of grants from the Medical Research Council, International Atomic Energy Agency, and Glaxo Laboratories.
REFERENCES

Barnett, E., and Nordin, B. E. C. (1960). Clin. Radiol., 11, 166. - (1961). Brit. J. Radiol., 34, 683.

Bywaters, E. C. L. (1948). Clin. Sci., 6, 281.

Doyle, F. H. (1961). Brit. J. Radiol., 34, 698.

Keane, B. E., Spiegler, G., and Davis, R. (1959). Ibid., 32, 162.

Koch, W., and Kaplan, D. (1961). Lancet, 1, 377.

Mayo, K. M. (1961). Brit. J. Radiol., 34, 693.

Nordin, B. E C. (1960), Clin. Orthop., 17, 235.

(1961). Lancet, 1, 1011.

\section{METABOLISM OF ${ }^{59} \mathrm{Fe}-\mathrm{SORBITOL}$ COMPLEX IN MAN}

BY

\section{G. WETHERLEY-MEIN, M.D.}

J. G. BUChaNAN, M.B., Ch.B. U. H. GLASS, F.I.M.L.T.

AND

\section{C. PEARCE, A.R.T. (Canada)}

Louis Jenner Laboratory, St. Thomas's Hospital and Medical School, London

Recent reports of the satisfactory response of irondeficient patients to intramuscular administration of an iron-sorbitol-citric-acid complex (iron-sorbitol) (Andersson, 1961 ; Swedberg, 1962) suggested an investigation in man of the injection-site clearance, organ distribution, and utilization for haemoglobin synthesis of this complex labelled with ${ }^{59} \mathrm{Fe}$. The pattern of the investigation reported here is similar to the investigation of ${ }^{59} \mathrm{Fe}$ labelled iron dextran previously carried out in this department (Grimes and Hutt, 1957).

\section{Materials and Subjects}

${ }^{59} \mathrm{Fe}$-labelled Iron-sorbitol. - The physical and chemical properties of stable iron-sorbitol are described elsewhere (Lindvall and Andersson, 1961 ; Svärd, 1961 ; Svärd and Lindvall, 1961). The material used in the present study was prepared on a laboratory scale by standard manufacturing technique to contain $50 \mathrm{mg}$. of iron and about $10 \mu \mathrm{c}$. of ${ }^{59} \mathrm{Fe}$ per $\mathrm{ml}$. The labelled material was checked by electrophoresis and gel-diffusion technique and demonstrated identical properties with the commercially available product " jectofer." The preparation was made available in 2-ml. ampoules.

Subjects.-Ten patients were studied. The clinical diagnosis, age, and initial haematological findings are shown in the Table. Cases 1, 2, and 3 were regarded as haematologically normal controls, although, in retrospect, Case 2 may have been marginally iron-deficient. The remaining seven patients had varying degrees of untreated iron deficiency. All were, by selection, in the fourth decade or older.

\section{Methods}

Administration and Dosage.-Eight of the patients were given $1.5-1.6 \mathrm{ml}$. of labelled iron-sorbitol intramuscularly (75 mg. iron: $10 \pm 2 \mu \mathrm{c}$. ${ }^{59} \mathrm{Fe}$ ). In Case 1 the use of the buttock as injection site invalidated surface counting over the sacrum, and in the remaining seven patients (Cases 2, 3, 4, 7, 8, 9, and 10) the deltoid site was used. The two patients (Cases 5 and 6) in whom the iron was given intravenously received only $0.5 \mathrm{ml}$. of iron-sorbitol ( $25 \mathrm{mg}$. iron : $3-4 \mu \mathrm{c} .{ }^{59} \mathrm{Fe}$ ), since 
Summary of Results in 10 Patients Receiving ${ }^{59} \mathrm{Fe}$ Sorbitol

\begin{tabular}{|c|c|c|c|c|c|c|c|c|c|c|c|c|}
\hline $\begin{array}{l}\text { Case } \\
\text { No. }\end{array}$ & Age & Diagnosis & $\begin{array}{c}\mathrm{Hb} \\
\mathrm{g} . \\
100 \mathrm{ml} \text {. }\end{array}$ & M.C.H.C. & $\underset{\mathrm{Fe}}{\text { Serum }}$ & $\begin{array}{c}\text { Injec- } \\
\text { tion } \\
\text { Route }\end{array}$ & $\begin{array}{l}\text { \% I.D. } \\
\text { Excreted } \\
\text { in Urine }\end{array}$ & $\begin{array}{c}\text { \% I.D. } \\
\text { at } \\
\text { Injection } \\
\text { Site } \\
\text { T + 10 Days }\end{array}$ & $\begin{array}{l}\% \text { I.D. in } \\
\text { Plasma } \\
\mathbf{T}+10 \text { Days }\end{array}$ & $\begin{array}{l}\text { Utilization } \\
\text { of } \\
\text { I.D. } \\
\text { T + 10 Days }\end{array}$ & $\begin{array}{c}\text { \% } \\
\text { Utilization } \\
\text { Retained } \\
\text { Dose } \\
\mathrm{T}+10 \text { Days }\end{array}$ & $\begin{array}{c}\% \text { I.D. } \\
\text { Unaccounted }\end{array}$ \\
\hline $\begin{array}{r}1 \\
2 \\
3 \\
4 \\
5 \\
6 \\
7 \\
8 \\
9 \\
10\end{array}$ & $\begin{array}{l}58 \\
71 \\
49 \\
36 \\
76 \\
44 \\
50 \\
45 \\
82 \\
38\end{array}$ & $\begin{array}{l}\text { Myocardial infarct } \\
\text { Angina } \\
\text { Myocardial infarct } \\
\text { Menorrhagia .. } \\
\text { Carcinoma of stomach } \\
\begin{array}{l}\text { Menorrhagia } \\
\text {.. }\end{array} \\
\begin{array}{l}\text { Polyarthritis } \\
\text { Carcinoma of stomach } \\
\text { Haematuria }\end{array} \text {.. }\end{array}$ & $\begin{aligned} 14 \cdot 9 \\
12 \cdot 6 \\
15 \cdot 3 \\
10 \cdot 3 \\
7 \cdot 4 \\
7 \cdot 7 \\
9 \cdot 3 \\
12 \cdot 6 \\
6 \cdot 4 \\
8 \cdot 0\end{aligned}$ & $\begin{array}{l}33 \\
31 \\
38 \\
26 \\
27 \\
27 \\
25 \\
30 \cdot 7 \\
25 \\
29\end{array}$ & $\begin{array}{l}\overline{53} \\
66 \\
66 \\
42 \\
34 \\
66 \\
15 \\
54\end{array}$ & $\begin{array}{l}\text { I.M. } \\
\text {," } \\
\text { I.". } \\
\text { I."M. } \\
\text { ", } \\
\text {," }\end{array}$ & $\begin{array}{l}42 \cdot 0 \\
34 \cdot 5 \\
23 \cdot 0 \\
31 \cdot 1 \\
10 \cdot 6^{*} \\
53 \cdot 0 \\
33 \cdot 4 \\
32 \cdot 2 \\
18 \cdot 5 * \\
18 \cdot 3\end{array}$ & $\begin{array}{l}3 \cdot 6 \\
6 \cdot 3 \\
4 \cdot 4 \\
4 \cdot 0 \\
= \\
\overline{1 \cdot 0} \\
3 \cdot 5 \\
2 \cdot 0 \\
0\end{array}$ & $\begin{array}{l}0 \\
0 \\
2 \cdot 1 \\
0 \\
0 \\
0 \\
0 \\
0 \\
2 \cdot 3 \\
0\end{array}$ & $\begin{array}{l}33 \cdot 0 \\
27 \cdot 8 \\
26 \cdot 9 \\
41 \cdot 7 \\
40 \cdot 8 \\
51 \cdot 0 \\
49 \cdot 6 \\
37 \cdot 0 \\
48 \cdot 0 \\
66 \cdot 5\end{array}$ & $\begin{array}{r}61 \cdot 0 \\
46 \cdot 9 \\
38 \cdot 1 \\
64 \cdot 3 \\
108 \cdot 0 \\
75 \cdot 5 \\
57 \cdot 5 \\
74 \cdot 9\end{array}$ & $\begin{array}{c}21 \cdot 4 \\
31 \cdot 4 \\
40 \cdot 6 \\
23 \cdot 2 \\
\overline{0} \\
16 \cdot 0 \\
27 \cdot 3 \\
15 \cdot 2\end{array}$ \\
\hline
\end{tabular}

the toxicity of larger doses of the preparation when given in this way is not known. In neither patient was there any subjective or objective reaction. In all cases aliquots were retained for determining the activity of the injected dose.

Surface Counting.-Changes in activity over injection site, control site (opposite arm or buttock), heart, liver, spleen, and marrow (sacrum) were recorded at selected time intervals from $T+2$ minutes to $T+10$ days. The apparatus and technique used have been previously described (Wetherley-Mein, Hutt, Langmead, and Hill, 1956). The observed activities of each organ were corrected for decay and counter variation and finally expressed as a percentage of the activity of that organ at $\mathrm{T}+2$ minutes.

Plasma and Red-cell Activity.-Blood samples were obtained at each surface-count determination throughout the period $T+2$ minutes to $T+10$ days. For each sampling time $5 \mathrm{ml}$. of plasma and $5 \mathrm{ml}$. of haemolysed whole blood were counted separately in a well-type scintillation counter. Blood volume was determined by a ${ }^{51} \mathrm{Cr}$ dilution technique (Mollison, 1960). Total plasma and red-cell activities at each sampling-time were then calculated and expressed as the percentage of the injected dose circulating at that time.

Urinary Excretion.-All urinary samples were collected during the period $\mathrm{T}+0$ to $\mathrm{T}+48$ hours. Time of voiding and volume of each sample were recorded and 5-ml. aliquots were counted in the well-type scintillation counter. The percentage of the injected dose excreted in each sample was determined. In two patients (Cases 5 and 9) urinary collection was incomplete.

Plasma Iron.-This was determined by the method of Bothwell and Mallett (1955).

Other Haematological Data.-These were obtained by standard techniques (Dacie, 1956).

\section{Results}

Clearance from Injection Site.-In Case 1 the use of the buttock invalidated the results and in Cases 5 and 6 the injection was intravenous. There was rapid clearance from the deltoid injection site in the remaining patients (Figs. 1 and 2). In the iron-deficient patients the mean $T \frac{1}{2}$ clearance was 46 minutes (range 36-82 minutes) and in the two remaining normal controls 174 minutes (range 115-200 minutes). At $T+10$ days the mean residual activity at the injection sites, expressed as a percentage of the activity at $\mathrm{T}+2$ minutes, was $2 \%$ (range $0-4 \%$ ) in the iron-deficient patients and $7.5 \%$ (range 6-9\%) in the normal controls.

Urinary Excretion.-In all patients there was a considerable urinary excretion of labelled iron in the 24hour period after injection, and this appeared to be maximal in the first 12 hours (Fig. 3). The most rapid loss occurred in the one patient receiving the dose intravenously in whom complete urinary collection was obtained (Figs. 3 and 4). The percentages of the injected doses excreted during the whole 48-hour period of urinary collection are shown in the Table.

\section{Body Distribution After Injection}

The mean ${ }^{59} \mathrm{Fe}$ surface patterns and the mean plasma and red-cell ${ }^{59} \mathrm{Fe}$ activity in the iron-deficient patients,

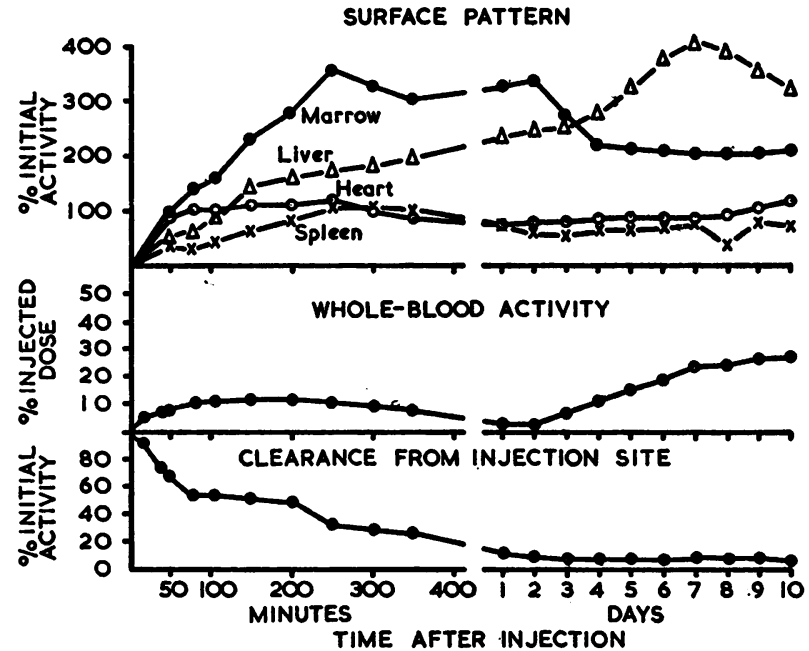
FIG. 1.-Mean of findings in control patients after intramuscular

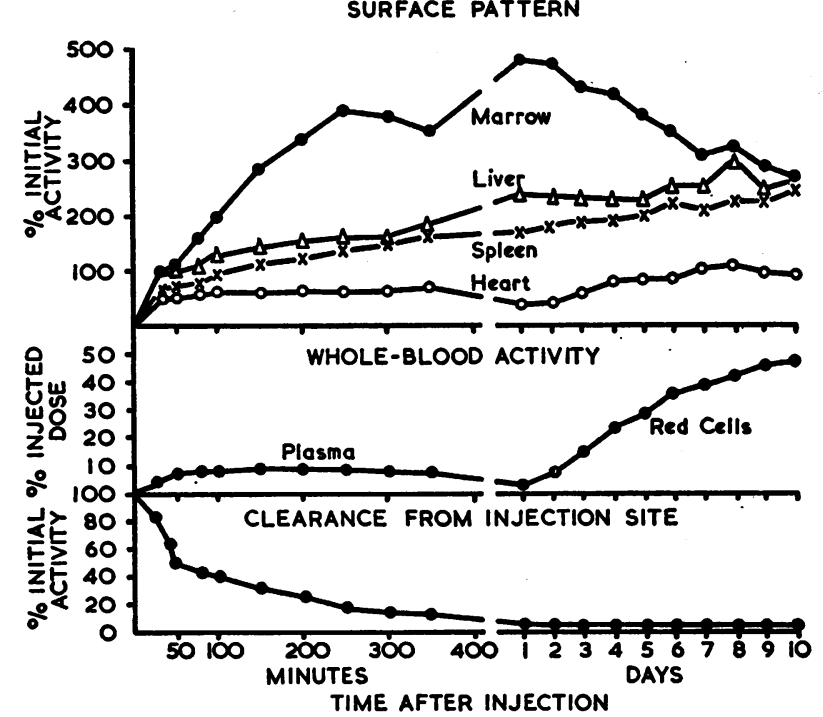

FIG. 2.-Mean of findings in iron-deficient patients after intramuscular ${ }^{50} \mathrm{Fe}$ sorbitol. 
the control patients, and the patients who received intravenous iron-sorbitol are shown in Figs. 1, 2, and 5.

Marrow Uptake.-In the patients receiving intramuscular doses (Figs. 1 and 2) the marrow curves are very similar to those obtained in normal and irondeficient patients receiving intravenous tracer doses of ${ }^{59} \mathrm{Fe}$ citrate (Ledlie and Baxter, 1954 ; Wetherley-Mein et al., 1956) and indicate an initial marrow accumulation of iron as it is cleared from the plasma and a subsequent decrease in marrow concentration as the label enters the circulation incorporated in red-cell haemoglobin. Although quantitative interpretation of these surface patterns is difficult the findings suggest a

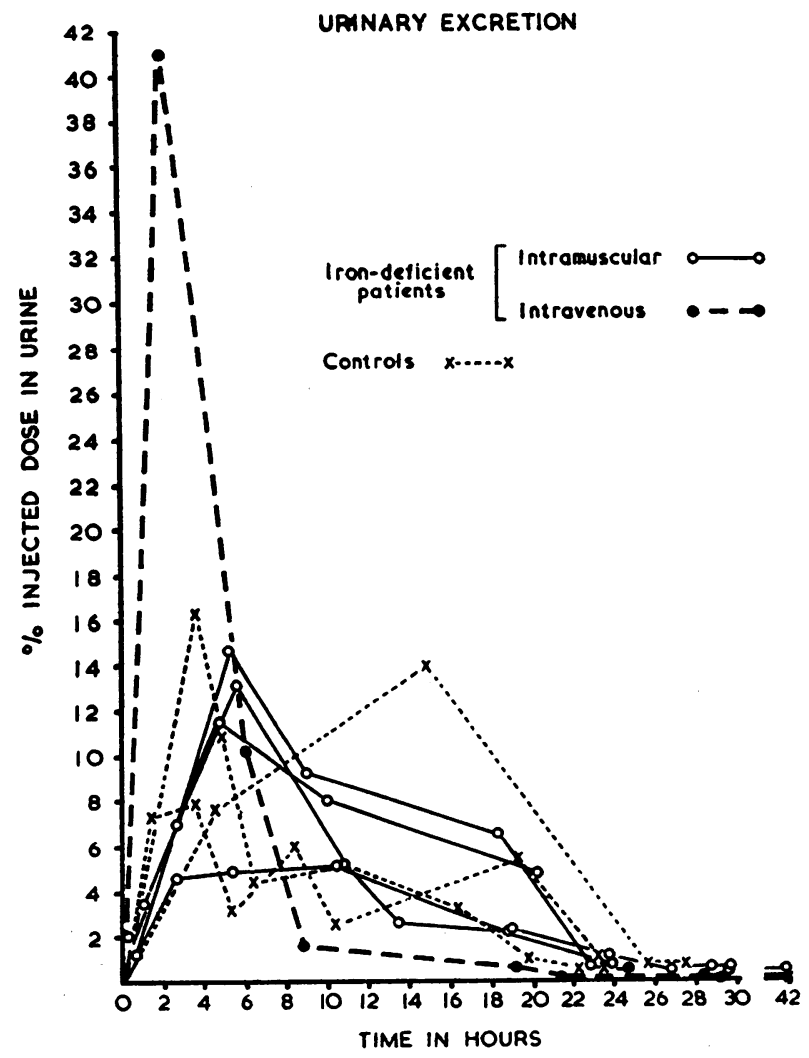

FIG. 3.-Urinary excretion of ${ }^{89} \mathrm{Fe}$ sorbitol in all patients.

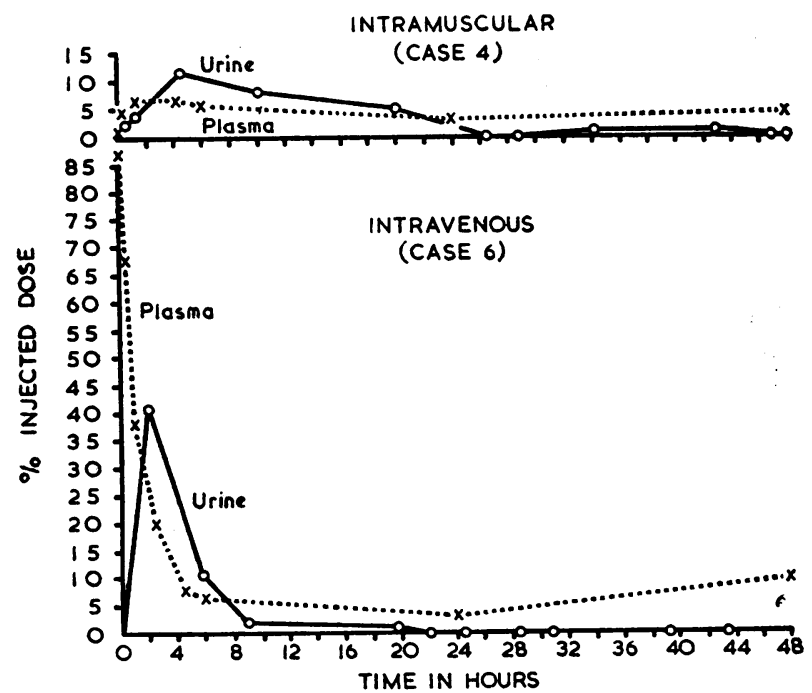

Fig. 4.-Comparison of urinary excretion and plasma activity in patients receiving ${ }^{\circ \circ} \mathrm{Fe}$ sorbitol. greater deviation of iron to the marrow in the irondeficient patients and to the liver in the controls.

Plasma and Red-cell Activity.-Measurement of activity in plasma and whole-blood samples showed little overlap of plasma and red-cell activity. Wholeblood activity in the first 24 hours after injection was due essentially to isotope carried in the plasma and subsequently to isotope in red cells. The curves representing plasma activity in the intravenous group (Fig. 5), presumably the resultant of urinary excretion and clearance to marrow and other sites, are virtually exponential and resemble the clearances observed after intravenous ${ }^{59} \mathrm{Fe}$ citrate. In both the intramuscular groups (Figs. 1 and 2) the plasma curves over the first five hours are modified by continued entry of label from the injection site and from $T+1$ hour to $T+4$ hours a steady state obtained with constant plasma activity. The red-cell-utilization curves (Figs. 1, 2, and 5) show, in all groups, entry of labelled cells to the circulation at about $\mathbf{T}+24$ hours, an initial phase of relatively rapid increase in activity, and, particularly in the control group, flattening of the curves by $T+7$ to $T+10$ days. The fractions of the injected doses used for haemoglobin

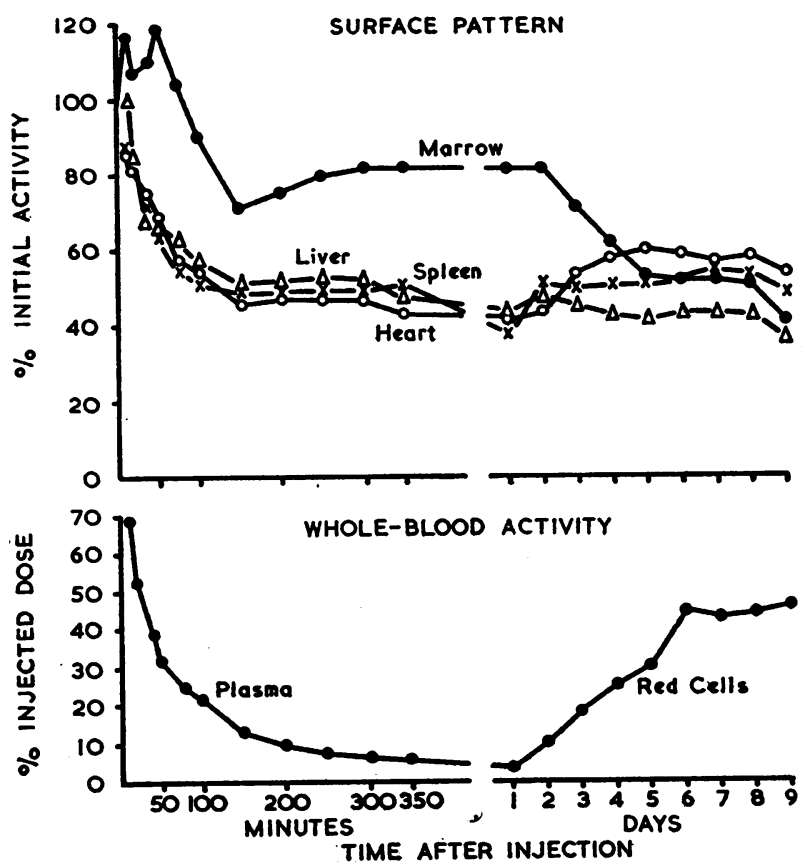

FIG. 5.-Mean findings in iron-deficient patients receiving intravenous ${ }^{89} \mathrm{Fe}$ sorbitol.

synthesis (\% utilization) by $\mathbf{T}+10$ days are shown in the Table. It can be seen that the percentage utilizations in the iron-deficient group are all greater than any in the control group. The $t$-test showed that the difference between the means of these groups was significant at the $5 \%$ level.

\section{Distribution to Liver}

It was hoped that the surface counting data would give some indication of the role of the liver in the handling of the iron-sorbitol complex. The findings in the intravenous group (Fig. 5) are unhelpful, since the surface data are obviously dominated by the changes in plasma activity. In the intramuscular groups (Figs. 1 and 2) there is, particularly in the normal controls, a steady rise in liver activity during the period $T+1$ to $T+6$ hours. Since during this phase heart and plasma 
activity remains constant, it is probable that this represents accumulation of isotope in the liver. Since we did not feel that valid results could be obtained by correction of surface data for organ bloodflow, no interpretation of the liver curves during the period of increasing red-cell activity $(T+2$ to $T+10$ days) can be made. However, in the Table it will be seen that varying proportions of the injected dose cannot be accounted for in terms of urinary excretion, residue at injection site, or appearance in red cells. It seems possible that this moiety may be held in the liver or other reticulo-endothelial sites.

\section{Discussion}

Although the metabolism of injected ${ }^{59} \mathrm{Fe}$ sorbitol in general resembles that of ${ }^{59} \mathrm{Fe}$ dextran and ${ }^{59} \mathrm{Fe}$ citrate there are certain important differences which are probably determined by the low molecular weight and the initial stability of the iron-sorbitol-citricacid complex in the plasma.

After intramuscular injection the rates of removal of the ${ }^{59} \mathrm{Fe}$-sorbitol complex and ${ }^{59} \mathrm{Fe}$ dextran are strikingly different. Grimes and Hutt (1957) found $T \frac{1}{2}$ buttock clearance times ranging from 10 to 40 hours as compared with the mean $\mathrm{T} \frac{1}{2}$ deltoid clearance times for ${ }^{59} \mathrm{Fe}$ sorbitol of 46 minutes (iron-deficient group) and 174 minutes (controls) observed in this study. Grimes and Hutt, unlike ourselves, found no difference in clearance rates between iron-deficient and control patients, but the numbers of patients in each group in their series and ours are probably too small for this difference to be significant. Clearance of the ${ }^{59} \mathrm{Fe}$ sorbitol from the injection site is almost complete by 10 days (Table, Figs. 1 and 2), whereas Grimes and Hutt found that $17-40 \%$ of the ${ }^{59} \mathrm{Fe}$ dextran remained at the site after $450-1,224$ hours. Use and movement of the muscle injected certainly affects absorption from it, and in our patients, at bed rest, the injection of a relatively small volume $(1.5 \mathrm{ml}$.) into the deltoid might be expected to produce more rapid absorption than the larger volumes $\left(5 \mathrm{ml}\right.$.) given in the buttock in the ${ }^{59} \mathrm{Fe}$ dextran study. However, the findings in one patient (Case 1) who received a buttock injection suggested that the use of the deltoid site did not obviously modify the clearance rates, and it seems most probable that the differences in clearance of ${ }^{59} \mathrm{Fe}$ sorbitol and ${ }^{59} \mathrm{Fe}$ dextran are a function of the different molecular weights of the two substances.

This view is supported by the results of studies on mechanisms of absorption from muscle in animals. Barnes and Trueta (1941) showed that toxins and snake venoms with molecular weights of $5,000-20,000$ were directly absorbed by the blood-stream while with molecular weights greater than 20,000 absorption was by lymphatics. The molecular weights of the ironsorbitol complex are of the order of 5,000 (Eriksson, 1961), and it has been established that this substance is primarily absorbed by the capillaries (Svärd and Lindvall, 1961), while the ${ }^{59} \mathrm{Fe}$ dextran, with a molecular weight certainly greater than 20,000 , is absorbed primarily by lymphatics (Beresford, Golberg, and Smith, 1957).

Although after its absorption into the blood-stream it seems that some fraction of the iron of the ${ }^{59} \mathrm{Fe}$ sorbitol complex becomes bound to transferrin (Svärd and Lindvall, 1961), the greater part of it, like ${ }^{59} \mathrm{Fe}$ dextran, is stable and is cleared from the plasma unchanged. In this respect both these substances differ from the iron of ${ }^{59} \mathrm{Fe}$ citrate, virtually all of which is immediately bound to transferrin if this is available (Loeffler, Rappoport, and Collins, 1955).

Both the dextran and the citrate iron thus come to exist in the plasma in high-molecular-weight complexes and, as such, are completely available for clearance from the plasma to marrow and reticulo-endothelial storage sites such as the liver. In contrast, although varying proportions of the ${ }^{59} \mathrm{Fe}$-sorbitol complex are also cleared to marrow and liver, its existence in the plasma predominantly as a substance of low molecular weight permits its excretion in the urine. The relationship between plasma activity and urinary loss (Fig. 4), particularly in the patient receiving it intravenously (Case 6), suggests that the rate of urinary excretion is a direct function of the plasma level. This is obviously of some importance in terms of optimal route and therapeutic dose, since animal studies suggest that increasing doses are associated with increased plasma levels (Lindvall and Andersson, 1961) and presumably, therefore, with increased urinary loss.

The findings in the present study demonstrate that, like ${ }^{89} \mathrm{Fe}$ dextran and ${ }^{59} \mathrm{Fe}$ citrate, the ${ }^{59} \mathrm{Fe}$ sorbitol not excreted in the urine moves from plasma to marrow and probably to liver as well, its partition between marrow and liver being possibly a function of the degree of iron deficiency. The utilization curves of all these preparations are similar and, in all, labelled iron appears in erythrocytes about 24 hours after injection. The 10-day utilization of tracer doses of ${ }^{59} \mathrm{Fe}$ citrate is between $70 \%$ and $85 \%$ in control patients and $100 \%$ in iron-deficient patients. In the previous iron-dextran and the present iron-sorbitol studies, where therapeutic rather than tracer doses were used, the 10-day utilization of the available fractions of the injected dose was, not surprisingly, almost invariably lower than this (see Table). The findings in the present study and in animal studies suggest that the fractions of iron-sorbitol unaccounted for by $T+10$ days are stored in the liver and possibly diffuse into tissue fluids (Lindvall and Andersson, 1961; S. Wahlqvist, 1962, personal communication).

Longer-term studies in untreated patients will be necessary to determine whether this stored fraction is readily available for haemoglobin synthesis, but comparison of the utilization curves of the iron-deficient and control patients (Figs. 1 and 2) suggests that in the iron-deficient group maximal utilization has not occurred by $T+10$ days and that there is further utilization of the stored fraction.

\section{Summary}

Studies with ${ }^{59} \mathrm{Fe}-$ labelled iron-sorbitol complex in man showed that after intramuscular injection there was rapid clearance from the site of injection.

The mean $\mathrm{T} \frac{1}{2}$ deltoid clearance for ${ }^{59} \mathrm{Fe}$ sorbitol was 46 minutes in the iron-deficient group and 174 minutes in the controls. Clearance from the injection site was almost complete by ten days. These ${ }^{59} \mathrm{Fe}$ sorbitol clearance times from the injection site are strikingly shorter than those for iron dextran.

It seems probable that the differences in clearance of ${ }^{59} \mathrm{Fe}$ sorbitol and ${ }^{59} \mathrm{Fe}$ dextran are a function of the different molecular weights of the two substances. 
The low molecular weight of iron-sorbitol complex resulted in a rapid excretion in the urine. This was maximal in the first twelve hours. The urinary excretion for the 48 -hour period after injection ranged from $18 \%$ to $53 \%$.

The red-cell utilization at ten days ranged from $27 \%$ to $66 \%$. Utilization in the iron-deficient group was greater than in the control group. The utilization curve in the iron-deficient group showed that maximal utilization had not occurred by $T+10$ days.

The surface counting data suggested that the retained fraction of iron not utilized for haemoglobin synthesis by $T+10$ days $(16 \%$ to $40 \%)$ was stored predominantly in the liver.

We are grateful to Dr. S. Wahlqvist, of Astra, Sweden, for providing the ${ }^{89} \mathrm{Fe}$ sorbitol. The expenses of the investigation were partly borne by the Endowment Fund, St. Thomas's Hospital.

\section{REFEREATCBS}

Andersson, N. S. E. (1961). Brit. med. J., 2, 275.

Barnes, J. M., and Trueta, J. (1941), Lancet, 1, 623.

Beresford, C. R., Golberg, L., and Smith, J. P. (1957). Brit. J. Pharmacol., 12, 107.

Bothwell, T. H., and Mallett, B. (1955). Biochem. J., 59, 599.

Dacie, J. V. (1956). Practical Haematology, 2nd ed. Churchill, Londion.

Eriksson, F. R (1961), Quoted by Svärd and Lindvall (1961)

Grimes, A. J., and Hutt, M. S. R. (1957). Brit. med. J., 2, 1074

Ledlie, E. M., and Baxter, C. F. (1954). Proceedings of 2 nd Radio-active Isotope Conference, p. 97. Butterworths, London.

Lindvall, S., and Andersson, N. S. E. (1961). Brit. J. Pharmacol., 17, 358 .

Loefflet, R K, Rappoport, D. A and Collins, V. P. (1955) Proc. Soc. exp. Biol. (N.Y.), 88, 441.

Mollison, P. L. (1960). Recent Advances in Clinical Pathology, edited by S. C. Dyke, p. 223. Churchill, London.

Svärd, P. O. (1961). J. Pharm. Pharmacol.. 13, 641.

- and Lindvall, S. (1961). Ibid., 13, 650.

Swedberg, B. (1962). Proceedings of 8th Congress of European Society of Haematology, p. 254. Karger, Basel.

Wetherley-Mein, G., Hutt, M. S. R., Langmead, W. A., and Hill, M. J.'(1956). Brit. med. J., 1, 1445.

\title{
SARCOMA INDUCTION BY IRON-CARBOHYDRATE COMPLEXES
}

\author{
J. FIELDING, M.R.C.P., D.P.H. \\ Consultant Haematologist, Paddington General Hospital, London
}

\section{[With Special Plate]}

In order to administer iron parenterally without incurring the toxic effects of the ionized metal, ferric hydroxide has been bound to carbohydrates to form complexes of fairly high molecular weight. These complexes simulate the binding of iron by the betaglobulin transferrin, the physiological carrier of iron in the circulation. The first clinically useful carbohydrate complex was made with saccharose, later with dextrans and dextrins, and more recently with sorbitol. In 1959 Richmond reported that iron-dextran ("imferon") induced sarcomas in rats after intramuscular injection in massive doses. Haddow and Horning (1960) confirmed this in both rats and mice. This unexpected observation restimulated interest in the role which metals may play in carcinogenesis ; it also demanded reconsideration of the use of iron-carbohydrate complexes in man for the parenteral treatment of iron deficiency.

The discussion has centred mainly on the massive dose of iron complex used to induce sarcomas in experimental animals. Golberg and his co-workers emphasized the systemic effects of massive iron overload, which include reticulo-endothelial stimulation, altered tissue enzyme activity, increased tissue peroxide and lipofuscin polymer formation, indicative of defective vitamin- $\mathrm{E}$ metabolism. They propose that the iron dosage given to experimental animals should be compared to the dosage used in treatment on a body-weight basis in order to assess the possible tumour risk in man. They point out that similar biochemical changes occur at the site of injection, and postulate that the bulk of tissue available for injection relative to the amount injected is also relevant (Golberg et al., 1960 ; Baker et al., 1961).

Haddow and Horning (1960) concluded that sarcoma induction by iron-dextran is essentially a local action. This implies that the absolute amount of iron injected is the determinate factor rather than the body-weight/ dose ratio (Haddow, 1960).
Most experimental work so far has been with mice and rats, which are evidently highly susceptible species. Haddow and Horning record a single induced tumour in a hamster ; they failed to produce tumours in guineapigs, but of three surviving rabbits in a group of six treated with massive iron-dextran one has produced a tumour after a latent period of 39 months (Haddow, 1961). Golberg and his co-workers (1960) failed to induce tumours in dogs.

Previously published experimental findings in rats are summarized in Table $\mathrm{I}$. Total dosages of $250 \mathrm{mg}$. or more of iron as iron-dextran given intramuscularly or subcutaneously in divided doses into a single site produce high yields of sarcomas varying from $55 \%$ to $92 \%$ of animals at risk. At such dose levels the sarcogenic action of iron-dextran is evidently easily reproducible in different laboratories with different strains of animal. The results of Golberg and his co-workers (1960) are of particular interest, since their experiments differed in design from others: the doses were given alternately into two limbs instead of into a single site. Injecting $116 \mathrm{mg}$. of iron as iron-dextran into each limb -that is, a total of $232 \mathrm{mg}$. Fe-they obtained only a $5 \%$ yield of tumours, compared with the much higher yields obtained when a similar total dose is given into a single site. There is perhaps evidence here which favours the "local action" hypothesis rather than the systemic effect of iron overload as the significant factor in iron sarcogenesis. Table I also shows a comparison made by Lundin (1962) of three iron complexes. He found that both iron-dextrin and iron-dextran in high dosage produced high yields of tumours in rats, whereas ironsorbitol produced a single tumour, which he described as a fibroma rather than a sarcoma. The significance of these results is discussed below.

The object of the experiment described here was to test the effect in mice of subcutaneous injection of a 